ТЕАТР, КІНО, ТЕЛЕБАЧЕННЯ

УДК 372.853.

\author{
Бугайова Вікторія Олександрівна, \\ кандидат мистеитвознавства, \\ кафедра режисури, \\ Харківська державна академія культури \\ Бурсаиький узвіз, 4, Харків, Україна, 61057, \\ https://orcid.org/0000-0002-4399-6587 \\ drama.vistava@gmail.com
}

\title{
КУРС «КРЕАТИВНЕ МИСЛЕННЯ В РЕЖИСЕРСЬКІЙ АРТ-ПРАКТИЦІ»: ІННОВАЦІЯ ЗМІСТОВО-ДИСЦИПЛІНАРНОГО ОНОВЛЕННЯ ФАХОВОГО ЗНАННЯ
}

Мета роботи - детально окреслити змістову проекцію курсу «Креативне мислення в режисерській арт-практиці», котрий в якості увиразнення образу обраної професії, професійної компетентності та кар'єрних орієнтацій майбутніх режисерів, можна вважати стрижньовим, головним чином у фокусі професійного становлення фахівців нової генерації. Методологія грунтується на проблемному підході та методах аналітики, що сприяють розчленуванню на складові та розкриттю зв'язків між смисловими вузлами представленого навчального курсу. Наукова новизна полягає в означенні дидактичної специфіки професійно-орієнтованого курсу «Креативне мислення в режисерській арт-практиці», який виявляє алгоритми здійснення i включення «механізмів творчості» як поєднання однозначного й багатозначного видів знання, часто несумісних сутностей, багатозначно-континуальних і однозначно-дискретних логік, що дозволяє реалізувати творче мислення - мислення креативне. Висновки. У світлі прогресивних методик викладання спецпредметів за нещодавно оновленими спеціальностями представлений курс «Креативне мислення в режисерській арт-практиці» постулює перетворення дії в одиницю творчої активності як особливо орієнтованої діяльності за рахунок збагачення іiі змісту, акцентуючи опанування кордонів і логік генерування інноваційних ідей в контексті креативної творчості як принципової канви режисури.

Ключові слова: професійно-орієнтована парадигма навчання; режисура; креативне мислення; латеральне мислення; генерація нових ідей.

Бугаёва Виктория Александровна, кандидат искусствоведения, кафедра режиссуры, Харьковская государственная академия культуры, Бурсачкий узвоз, 4, Харьков, Украина

Курс «Креативное мышление в режиссерской арт-практике»: инновация содержательно-дисциплинарного обновления профессионального знания

Цель работы - детально отразить смысловую проекцию курса «Креативное мышление в режиссерской арт-практике», который в качестве выражающего образ выбранной профессии, профессиональной компетентности и карьерных ориентаций будущих режиссеров, можно считать стержневым, главным образом в фокусе профессионального становления специалистов нового поколения. Методология основывается на проблемном подходе и методах аналитики, способствующих расчленению на составляющие и раскрытию связей между смысловыми узлами представленного учебного курса. Научная новизна заключается в означивании дидактической специфики профессионально-ориентированного курса «Креативное мышление в режиссерской арт-практике», который обнаруживает алгоритмы осуществления и включение «механизмов творчества» как сочетания однозначного и многозначного видов знания, часто несовместимых сущностей, многозначноконтинуальных и однозначно-дискретных логик, что позволяет реализовать творческое мышление - мышление креативное. Выводы. В свете прогрессивных методик преподавания спецпредметов по обновленным специальностям представленный курс «Креативное 
ISSN 2410-1176 (Print) Вісник КНУКіМ. Серія Мистецтвознавство. Вип. 39. ISSN 2616-4183 (Online)

мышление в режиссерской арт-практике» постулирует преобразования действия в единицу творческой активности как особо ориентированной деятельности за счет обогащения ее содержания, акцентируя освоение границ и логик генерирования инновационных идей в контексте креативного творчества как принципиальной канвы режиссуры.

Ключевые слова: профессионально-ориентированная парадигма обучения; режиссура; креативное мышление; латеральное мышление; генерация новых идей.

Buhaiova Viktoriia, PhD in Art Criticism, Department of Directing, Kharkiv State Academy of Culture, 4, Bursatskyi Uzviz, Kharkiv

The course "Creative Thinking in Directing Art Practice": innovation of contentdisciplinary renewal of professional knowledge

The purpose of the article is to reflect in detail the conceptual projection of the course "Creative Thinking in Directing Art Practice", which can be considered crucial as an expression of the chosen profession, professional competence and career orientations of future directors, mainly from the point of view of professional development of specialists of the new generation. The research methodology was based on the problem approach and methods of analytics, which facilitate the breakdown into components and the disclosure of links between the semantic nodes of the presented training course. The scientific novelty of the work consists in signifying the didactic specificity of the professionally oriented course "Creative Thinking in Directing Art Practice", which reveals algorithms for the implementation and inclusion of "creative mechanisms" as a combination of explicit and ambiguous types of knowledge, often incompatible essences, multivalued continuum and uniquely-discrete logics, which allows for realizing creative thinking. Conclusions. In the light of progressive methods of teaching special subjects within recently updated specialties, the presented course "Creative Thinking in Directing Art Practice" postulates the transformation of action into a unit of creative activity as a particularly focused activity by enriching its content, emphasizing the mastering of boundaries and the logic of generating innovative ideas in the context of creativity as a principal canvas of directing.

Key words: professionally-oriented teaching paradigm; directing; creative thinking; lateral thinking; generation of new ideas.

Вступ. Зумовлена соціокультурними реаліями сучасності освітня парадигма, додавши на нинішньому етапі особливу гостроту проблематиці вітчизняного освітнього простору в руслі вектора професіоналізації, актуалізує пошук педагогічних методологій і визначення шляхів їх впровадження в навчально-виховну систему, зокрема осмислення ресурсу освітніх технологій.

Базова функція професійної освіти - здійснення фахового самовизначення студента шляхом забезпечення зв'язку між «архівом» знань і набуттям професійного досвіду. У межах вітчизняної освітньої традиції, незалежно від сфери реалізації, набуття професійного досвіду не завжди апріорі закладено як невід'ємна складова фахового навчання, але ж це - єдиний цілісний процес - в цьому й полягає його значимість і специфіка (Антонова, 2012; Бордовский, 2001).

Принциповим компонентом професійної підготовки за спеціальністю «Сценічне мистецтво» можна вважати евристичний потенціал новітнього спецкурсу «Креативне мислення у режисерський арт-практиці», який експлікуючи конструктивний методологічний інструментарій, постає квінтесенцією операційного підходу до рішення проблеми розгортання суті професійної специфіки режисури.

Тож мета статті - детально відобразити змістову проекцію дисципліни «Креативне мислення у режисерський арт-практиці».

Виклад основного матеріалу. «Наріжний камінь» дисципліни «Креативне мислення у режисерський арт-практиці» - принцип органічної цільності змісту щодо відображення аспектів практики роботи за фахом, виокремлення «динамічної єдності формул» як саме майбутнім митцям генерувати нові творчі ідеї - обов'язкової складової практичного 
вирішення проблемних професійних завдань в контексті протидій режисерської практики, в якій шаблонні рішення виявляються недостатньо ефективними. Цей курс включає ледве не всі формальні методи створення ідей, розроблені до цього часу (Антонова, 2012; Библер, 1975; Пономарев, 1983; Эдвард де Боно, 2015).

Метою дисципліни $\epsilon$ навчання майбутнього режисера знаходити нестандартні, інноваційні рішення реалізації творчих ідей в контексті поліаспектного розуміння практичної їхньої реалізації. Завдання дисципліни: розкриття об'єкту, предмету, структури навчальної дисципліни «Креативне мислення у режисерський арт-практиці»; окреслення понятійного апарату та теорії «латерального мислення»; ознайомлення з техніками розвитку креативного мислення та їхнім практичним застосовуванням; розуміння процесу пошуку творчої ідеї свідомим та чітко структурованим.

Методичною основою курсу «Креативне мислення в режисерський арт-практиці» $є$ вчення відомого англійського спеціаліста в сфері творчого мислення, навчання навикам мислення Едуарда де Боно, а також творчі надбання К. Станіславського, В. Мейєрхольда, Л. Курбаса, Є. Вахтангова; творча та педагогічна спадщина Г. Товстоногова, І. Шароєва, С. Клітіна, Б. Петрова, Б. Шарварка, Д. Тихомирова, А. Коновича, А. Сіліна, А. Рубба, В. Зайцева та ін.

Щодо вимог до знань, умінь та навичок, то в результаті вивчення дисципліни студент повинен знати: термінологію та основні теоретичні поняття методик креативного мислення, визначення базових понять «латеральне мислення», «креативність», методика «шести капелюхів»; технологічні процеси пошуку творчої ідеї та засоби реалізації ії на практиці; методи управління та продюсування власної ідеї. Крім того, майбутній фахівець повинен уміти: застосовувати набуті знання в своїй професійній діяльності; обгрунтувати базове значення нових креативних ідей в структурі режисерської майстерності на естраді та відкритих майданчиках; самостійно мислити та знаходити необхідні виразні засоби для втілення режисерського задуму в естрадних виставах та масових видовищах; проаналізувати та дати об’єктивну оцінку результатів своєї самостійної (домашньої) роботи; забезпечити проведення репетицій, виготовлення декорацій, костюмів, реквізиту, використання музично-шумового оформлення свята із обов'язковим використанням нових креативних ідей. А також студент повинен мати навички: бути відкритим до нового творчого досвіду; толерантності щодо невизначеності; творчої інтуїції, уяви та фантазї; прудкості та оригінальності творчого мислення; організації та проведення практичних семінарів щодо розвитку креативного мислення.

Детально представимо навчальну дисципліну, яка складається з пов'язаних між собою загальною логікою викладення матеріалу 9 тем:

Тема 1. Вступ. Предмет і завдання курсу «Креативне мислення режисера». Виразні засоби театралізації сучасних форм відпочинку. Зміст, якості, функції. Визначення основних понять: «творчість», «креативність», «мислення», «латеральність», «паралельне мислення» тощо. Аналіз основної літератури з курсу.

Тема 2. Системно-креативне мислення режисера. Креативне мислення, суть та значення. Інтуїтивний, новаторський та натхненний типи мислення. Вплив оточуючого середовища на креативність. Типи креативності. Роль особистості в креативності, визначення особистісного креативного потенціалу. Профіль креативного потенціалу. Дослідження креативного процесу. Методи креативного вирішення проблем. Роль креативних технологій мистецтва. Як працюють креативні лідери. Креативність і організаційна культура. Поведінка креативних людей. Креативність, яка включає: по-перше, інтелектуальні передумови творчої діяльності, що дає змогу створювати щось нове, раніше невідоме, а також попередній набір знань і умінь необхідних для того, щоб це нове створити; по-друге, особисті якості, які дають змогу продуктивно діяти в ситуаціях невизначеності, виходити за межі передбаченого, проявляти спонтанність; по-третє, «метатворчість» як життєву позицію людини, що ставить собі за мету високу цінність свободи, відмову від шаблонності, стереотипності в думках і 
діях, бажання сприймати і створювати щось нове, змінюватися самому і змінювати світ довкола себе.

Тема 3. Методика «Латерального мислення». Латеральне мислення - метод нестандартного підходу до вирішення завдань (термін, що описує принцип цілої наукової концепції, запропоновано в кінці 1960-х рр. Едвардом де Боно, одним 3 авторитетніших в світі експертів сфери креативності). Латеральне мислення як «скачок» у будь-якому напрямі творчості. Творча помилка як проміжний крок, що не призводить до відповідних наслідків.

Тема 4. Методика мислення «Шести капелюхів». Метод шести капелюхів, що дає змогу структурувати і зробити набагато ефективнішим будь-яку розумову роботу. В основі «Шести капелюхів» закладена ідея паралельного мислення як простий і практичний спосіб здолати труднощі за допомогою розділення процесу мислення на шість різних режимів, кожен з яких представлений капелюхом свого кольору: червоний - емоції, а звідси - інтуїція, відчуття і передчуття; жовтий - переваги; чорний - обережність; зелений - творчість, пошук альтернатив; білий - інформація і питання: що маємо, чого не вистачає?; синій - організація мислення: чого досягли і що робити далі? Змінюючи головний убір, можна переходити на різні аспекти тієї чи іншої проблеми.

Тема 5. Принципи творчості та творчих рішень. Гнучка реакція на зміни. Вироблення творчих ідей. Формулювання проблем. Відхилення від стандарту. Творчість і щасливі осяяння. Відкриття в результаті осяянь. Відділення створення ідей від їх оцінки. Перевірка допущень: повсякденні допущення і переломні рішення. Перевірка допущень. Як уникнути шаблонного мислення. Створення нових перспектив. Зведення до мінімуму негативного мислення. Корегування негативного мислення. Перетворення незнайомого у звичне.

Тема 6. Прийоми-стимулятори креативного мислення. Типи методів креативного мислення. Мозковий штурм i «мозковий конспект». Зв'язані стимул-реакції проти незв'язаних. Як вибирати прийоми-стимулятори. Прийоми для вирішення стратегічних завдань. Прийоми-стимулятори для ідей, пов'язаних 3 новими виробами. Прийомистимулятори для удосконалення нових творчих ідей. Прийоми для вирішення проблем реклами і маркетингу. Прийоми-стимулятори для вирішення проблем людських ресурсів.

Тема 7. Індивідуальні прийоми-стимулятори: практикум. Ідеї навмання. «Видування» ідей. Тренінги-вправи: «Гнути, м'яти і ліпити». «Розум у позику», «Списати в сусіда». «Творче божевілля». Щоденник ідеї. Перейменування. Стереотип. Перемикання. Дзвінок будильника. Запозичене натхнення. Розповідь аналогічного повтору з додаванням власних ідей. «Мариновані мізки». Комбінації. Круг можливостей. Комбіноване базікання. Ящик ідей. Грати ідей. «Мультики ідей». Гра в іменники. «Шукач» іменників. Слова-діаманти. Картографування мозку. Карлючки. Перебільшення. В’язки ідей. Уявний наставник. Квітка лотоса. Заголовки бульварних газет. Прийоми «розворотів»: порушник закону, «перевертувачі», розворот. Прийоми типу «дуже схожий, тільки інший». Біонічні ідеї. Принцип використання органів чуття.

Тема 8. Групові прийоми-стимулятори: практикум. «Змішувач», «Картинна галерея», «Злива ідей». Модульний мозковий штурм. «Передати капелюх». Гра у різнокольорову пляшку. Щасливий квиток. Мозковий штурм з незв'язаними прийомами. Розрихлювач мозку: «лівомозкові» ідеї, «правомозкові» ідеї, об'єднані ідеї. Примусові асоціації. Міксер ідей. Басейн ідей. Організаційні мозкові штурми. Зміна станів. Повітряна кулька. Стрибаючий м’яч. Ескіз мозку. Карлючки усередині фігури. Вітальні листівки. Гра в імена. Фрагменти мозаїки. Інструментарій прийомів-стимуляторів.

Тема 9. Розвиток практичного інтелекту режисера. Визначення інтелекту. Теорії про природу інтелекту. Компоненти логічного і проблемного мислення. Компоненти інтелекту й отримання знання. Досвід та інтелект. Вдосконалення здатності визначати корінь проблеми. Вибір кроків, необхідних для вирішення творчої проблеми й вдосконалення здатності вибирати їх послідовність. Вибір стратегії для визначення порядку компонентів вирішення проблеми та іiі вдосконалення. Уявне представлення інформації: вибір 3 різноманіття. Контроль за результатами рішення. Компоненти придбання знань. Процеси 
придбання знань: вибіркове кодування, комбінування й порівняння. Контекстуальні ключі. Стратегії запам’ятовування. Природа прозорливості.

Методичні рекомендації до практичних занять та самостійної роботи студентів. Для проведення практичних занять необхідна простора аудиторія з розміщеними вздовж стін меблями та фліп-чарт. На стінах розміщуються результати практичної роботи. Необхідні матеріали: м'ячик середнього розміру, стікери різних кольорів; ручка і блокнот для кожного студента; кольоровий папір принаймні 6 кольорів (червоний, білий, чорний, зелений, синій, жовтий); степлер, клей, ножиці; фломастери, маркери, аркуші паперу для малювання. Перед кожним практичним заняттям, яке відбувається у формі тренінгу, викладач визначає головні правила тренінгу: активність, безоціночність, позитивність (група сама формує правила, за якими вона буде працювати, але ці 4 правила обов'язкові).

Обговорюючи результати практичного заняття, не рекомендується оцінювати його, а лише аналізувати: що спільного і що відмінного, позитивного чи негативного, нюанси, які помітила одна група і не помітила інша, різні аспекти творчих понять, схожість /відмінність 3 визначеннями інших тощо. Викладачеві обов'язково необхідно стежити за часом, не переходити на особистості, надавати можливість студентам виступати по черзі, стежити за чітким використання методу, не перетворювати заняття на хаос.

Адже робота над творчими задачами в межах тренінгів креативності дає змогу учасникам групи усвідомити головні етапи творчого процесу. Для того, щоб спонукати учасників звернути увагу на це, викладач перед тим, як дати умову завдання-тренінгу, просить звернути увагу на всі стани, які виникають у студентів, а під час обговорення вражень студенти розповідають про ці стани, їхні характерні особливості й динаміку.

Завдання до практичних занять та самостійної роботи студентів.

Тема 1. Вступ.

Самостійна робота студентів: аналіз фахової літератури.

Мета: 3'ясувати об'єктивні фактори та історичні підвалини виникнення та формування виразних засобів театралізації сучасних форм відпочинку. Засвоїти зміст, якості та функції креативного мислення режисера.

Завдання: 3'ясувати основні поняття 3 курсу «Креативне мислення режисера»; проаналізувати запропоновану літературу з курсу.

Тема 2. Системно-креативне мислення режисера естради та масових свят.

Самостійна робота студентів: роль особистості в креативності.

Мета: зрозуміти суть та значення креативного мислення.

Завдання: з'ясувати принципи інтуїтивного типу мислення й новаторського типу мислення; визначити сутність натхненного типу мислення.

Практичне заняття:

Мета: визначити взаємодію креативності й організаційної культури.

Питання: вживання креативності; креатив в освіті; риси характеру людини та профіль креативного потенціалу.

Тема 3. Методика «Латерального мислення» .

Самостійна робота студентів: принцип «Як піймати ідею за хвіст».

Мета: усвідомити етапи творчого процесу.

Завдання: зрозуміти принципи головних методик Є. Боно: CORT (розвиток інтелектуальних здібностей); Sixhats (самоорганізація мислення); професійна програма «De Bono Thinking 24x7».

Практичне заняття: методи фіксації творчих ідей.

Мета: визначити взаємодію креативності й організаційної культури.

Питання: принципи концепції Е. Боно; основні методи фіксації творчих ідей.

Тема 4. Методика мислення «Шести капелюхів».

Самостійна робота студентів: паралельне творче мислення.

Мета: ефективне використання навиків творчого мислення. 
Завдання: аналіз вправи «Акварель»; знайомство з основними методами творчого мислення: метод ТРІЗ (теорія рішення зображувальних завдань); ментальні карти (автор Тоні Б'юзен); синектика (автор - Вільям Гордон); метод фокальних об'єктів (автор - Чарльз Вайтинг); морфологічний аналіз (автор - Фріц Цвіккі); непрямі стратегії.

Практичне заняття: «Історії творчості».

Мета: проаналізувати основні прояви творчості та креативності на практиці.

Питання: сутність та відмінність методів творчого мислення; вправи, спрямовані на розвиток швидкості мислення, видобування інформації з пам'яті, здатності усвідомлено переходити в нові змістовні сфери.

Тема 5. Принципи творчості та творчих рішень.

Самостійна робота студентів: вироблення нових творчих ідей.

Мета: створення нових перспектив для творчості.

Завдання: відділення створення ідей від їх оцінки; вправи на корегування негативного мислення.

Практичне заняття: творче мислення на практиці.

Мета: перетворити незнайоме на звичне.

Питання: лідерство і проникливість у тренінгах; вибір завдання та вправи для розуму; лінійні вправи для розвитку та генерації творчих ідей.

Тема 6. Прийоми-стимулятори креативного мислення режисера.

Самостійна робота студентів: прийоми удосконалення нових творчих ідей

Мета: удосконалення нових творчих ідей.

Завдання: проаналізувати структуру С. Боно «5+».

Практичне заняття: інтуїтивні вправи-тренінги для творчого розуму.

Мета: стимулювання креативного мислення.

Питання: сутність тренінгів «Фальшиві обличчя», «Шматочки й кубики», «Бульбашки думок», «Решітка ідей»; питання «СКАМПЕР».

Тема 7. Індивідуальні прийоми-стимулятори: практикум.

Самостійна робота студентів: коучинг, усвідомленість і відповідальність.

Мета: зрозуміти сутність понять «коуч», «коуч-тренер».

Завдання: створення в межах тренінгу сприятливої атмосфери для освоєння креативних методик; проведення практичних вправ для розвитку креативного мислення і здобуття навичок застосування креативних методик у бізнесі; забезпечення учасників необхідною теоретичної базою та iї поєднання з практичними аспектами творчості; організація командної роботи, вдосконалення навичок ефективної партнерської співпраці в сфері пошуку нових ідей.

Практичне заняття: тренінг «КРЕАТИВНИЙ WEEKEND»

Мета: ознайомлення із фазами творчого процесу та їх застосування на практиці.

Питання: паралелі між критичним та креативним мисленням. Критичне мислення: аналітичне, конвергентне, вертикально спрямоване, містить ймовірність, базується на судженнях, сфокусоване, об'єктивне, задіює ліву півкулю мозку, вербальне, лінійне, результат - аргументація, умовивід. Креативне мислення: генеративне, дивергентне, спрямоване в інший бік, містить можливість, базується на припущеннях, розсіяне, суб'єктивне задіює праву півкулю мозку, візуальне, асоціативне, результат - новизна, широкий вибір.

Тема 8. Групові прийоми-стимулятори: практикум.

Самостійна робота студентів: вправи-тренінги на основі активізації сміху.

Мета: Сміх як новий принцип генерації креативності.

Завдання: визначити основний інструментарій прийомів-стимуляторів.

Практичне заняття: мозковий штурм на основі вправ 3 активним використанням рецепторів сміху.

Мета: окреслити вправи, що не пов'язані з загальною тематикою заняття та груповими прийомами-стимуляторами. 
Питання: ірраціональне мислення; кола позитивних можливостей; творчі ідеї в «малюнках»; традиційні техніки «мозкового» штурму.

Тема 9. Розвиток практичного інтелекту режисера естради та масових свят.

Самостійна робота студентів: компоненти логічного й проблемного мислення.

Мета: вдосконалення здатності визначати корінь творчої проблеми.

Завдання: розкрити зміст поняття «творча проблема»; розглянути творчу проблему як наскрізний процес, що входить в творче мислення; окреслити творчу проблему як механізм творчого мислення в творчості.

Практичне заняття: потокограма, куди стікаються творчі думки.

Мета: креативне мислення в дії: шість фігур мислення, оцінки та принципів дій

Питання: компоненти придбання творчих знань; процеси придбання творчих знань; природа прозорливості.

Загалом курс «Креативне мислення в режисерській арт-практиці» виявляє об'ємний, з різнорідними шарами, різними смисловими компонентами та «вимірами», актуальний погляд на креативне творення в режисурі.

Таким чином, у межах курсу представлено різні зони осмислення й ракурси щодо креативного творення, формо- і образотворних інновацій, що враховують інтегральність художності сценічної мови й фахових проблем режисури в контексті інноваційного стилю мислення. Названий курс постає не просто цільовим компонентом професійної орієнтації навчання за спеціальністю «Сценічне мистецтво», а навіть пріоритетним смисловим компонентом, бо саме завдяки йому й відбувається жорстка фіксація професійних завдань.

У світлі безпрецедентних змін сучасної освіти - кардинального осучаснення дисциплінарної проблематики, забезпечення іiі тісної взаємодії із практикою професійноорієнтовогого навчання, зокрема теоретико-практичної потреби суттєвого оновлення фахової освіти майбутнього режисера, найефективнішим результатом, спрямованим на пояснення смислу практичного осягнення мистецтва режисури, детермінуючою домінантою специфічної неповторності якого є креативність, можна вважати представлене у статті змістове наповнення дисципліни «Креативне мислення в режисерській арт-практиці», що активізує креативну творчість майбутніх спеціалістів й надає особливої продуктивності фаховому навчанню.

Наукова новизна полягає в означенні дидактичної специфіки професійноорієнтованого курсу «Креативне мислення в режисерській арт-практиці», який виявляє алгоритми здійснення і включення «механізмів творчості» як поєднання однозначного й багатозначного видів знання, часто несумісних сутностей, багатозначно-континуальних і однозначно-дискретних логік, що дозволяє реалізувати творче мислення - мислення креативне.

Висновки. У світлі прогресивних методик викладання спецпредметів за нещодавно оновленими спеціальностями представлений курс «Креативне мислення в режисерській артпрактиці» постулює перетворення дії в одиницю творчої активності як особливо орієнтованої діяльності за рахунок збагачення iї змісту, акцентуючи опанування кордонів і логік генерування інноваційних ідей в контексті креативної творчості як канви режисури, що у фокусі прогностики можна визначити перспективною i варіативною лінією оновлень змістово-дисциплнарного підгрунтя навчання.

\section{Список використаних джерел}

1. Антонова О. С. Сутність поняття креативності: проблеми та пошуки. Теоретичні $i$ прикладні аспекти розвитку креативної освіти у вищій школі. Житомир: Вид-во ЖДУ ім. I. Франка, 2012. 284 с.

2.Библер В. С. Мышление как творчество. Москва : Политиздат, 1975. 399 с.

3.Бордовский Г.А. Управление качеством образовательного процесса. СанктПетербург : РГПУ им. А. И. Герцена, 2001. 359 с.

4.Пономарев Я.А. Фазы творческого проиесса. Исследование проблем психологии творчества. Москва : Наука. 1983. 326 с. 
ISSN 2410-1176 (Print) Вісник КНУКіМ. Серія Мистецтвознавство. Вип. 39. ISSN 2616-4183 (Online)

5.Эдвард де Боно. Гениально! Инструменты ремения креативных задач. Москва : Альпина Паблишер, 2015. 381 с.

6.Эдвард де Боно. Искусство думать: латеральное мышление как способ решения сложных задач. Москва: Альпина Паблишер, 2015. 172 с.

\section{References}

1. Antonova, O. (2012). Sutnist poniattia kreatyvnosti: problemy ta poshuky. Teoretychni $i$ prykladni aspekty rozvytku kreatyvnoi osvity $u$ vyshchii shkoli [The essence of the concept of creativity: problems and searches. Theoretical and applied aspects of the development of creative education in higher education]. Zhytomyr: Publishing House of Zhytomyr State University named after I. Franko.

2. Bibler, V. (1975). Myshlenie kak tvorchestvo [Thinking as creativity]. Moscow: Politizdat.

3. Bordovsky, G. (2001). Upravleniye kachestvom obrazovatel'nogo protsessa [Quality management of the educational process]. St. Petersburg: Publishing house of Herzen State Pedagogical University of Russia.

4. Ponomarev, Ya. (1983). Fazy tvorcheskogo protsessa. Issledovanie problem psikhologii tvorchestva [Phases of the creative process. Study of the problems of psychology of creativity]. Moscow: Nauka.

5. Edward de Bono. (2015). Genial'no! Instrumenty resheniya kreativnykh zadach [Genius! Tools for solving creative tasks]. Moscow: Alpina Publisher.

6. Edward de Bono. (2015). Iskusstvo dumat': lateral'noe myshlenie kak sposob resheniya slozhnykh zadach [The art of thinking: Lateral thinking as a way of solving complex problems]. Moscow: Alpina Publisher.

(C) Бугайова В. О., 2018

Стаття надійшла до редакиії: 12.09.2018

УДК 792.086(477-25) “199/201”

Гапчук Юлія Олександрівна аспірантка,

Київський національний університет культури і мистеитв,

вул. С. Коновальия,36, Київ, Україна, 01133, https://orcid.org/0000-0003-2352-4168, Julia_di27@ukr.net

\section{АНТРЕПРИЗА В СЦЕНІЧНОМУ МИСТЕЦТВІ КИЕВА НАПРИКІНЦІ ХХ - ПОЧАТКУ ХХІ СТОЛІТЬ}

Мета дослідження - розкрити стан культурно-мистецької діяльності антрепризних театрів Києва. Методологія дослідження грунтується на принципі культурно-історичного підходу, який дає змогу висвітлити основні напрями культурно-мистецької діяльності антрепризних театрів Києва на сучасному етапі та з'ясувати форми та способи позиціонування різних театральних брендів, а також присутній метод класифікації, який допомагає розподілити незалежні театральні організації за формою підпорядкування. Наукова новизна розвідки полягає в тому, що вперше детально опрацьовано антрепризну форму театрального мистецтва, узагальнено досвід попередників із означеної проблеми, та надано комплексну картину антрепризним театрам, їх становленню, розподілу та видозмінам. Висновки. 3'ясовано, що антреприза посідає важливе місце в культурному середовищі вітчизняних незалежних театрів. Досліджено форми існування різних незалежних театральних одиниць. Висвітлено особливості формування репертуару і труп, способи позиціонування театральних брендів. На підставі здійсненого дослідження 